Iryna Lynova

ORCID iD 0000-0003-0335-8668

$\mathrm{PhD}$ in Pedagogy, Associate Professor, Senior Researcher of Department of Integration of Higher Education and Science, Institute of Higher Education, National Academy of Educational Sciences of Ukraine, 9 Bastionna Str., 01014 Kyiv, Ukraine, i.lynova1704@gmail.com

Oksana Bulvinska

ORCID iD 0000-0002-6764-4340

$\mathrm{PhD}$ in Pedagogy, Senior Researcher, Senior Researcher of Scientific-Research Laboratory of Educology, Borys Grinchenko Kyiv University, 13-b Tymoshenko Str., 04212 Kyiv, Ukraine, o.bulvinska@kubg.edu.ua

\title{
CONTINUING PROFESSIONAL DEVELOPMENT OF ACADEMIC STAFF: THEORETICAL APPROACHES AND MODELS
}

The article pays attention that usage of a definite theory in educational researches that gives distinct and reproducible explanation of professional experience, becomes the basis of the layout of a practical models of educational practices. It is suggested to classify theoretical approaches and concepts to continuing professional development at philosophical,pedagogical and psychologicallevels. It was proved that generalization of interconnected systematic synergetic, anthropological, axiological, acmeological, andragogical, and personality-based and activitybased approaches substantiate the aim, tasks, content, forms and methods of continuing professional development of academic staff, take into account self-direction and self-control of individual professional development, and at the same time making it possible to coordinate actions of teachers, make all the adjustments on time, to act on the basis of democracy. It was found out that practical models designed according to these approaches make it possible for the teachers to develop their own educational trajectory, to choose concrete forms, types, tendencies and subjects of educational services individually. But still there is unsolved problem of absence of regulated ways and informal education assessment criteria which is defined as individually controlled professional development, self-organized acquisition of professional competences by the teachers which is not documented. That is what limits possibilities of self-education and its importance for modernization of the system of higher education in Ukraine and for improving of professional practices of each teacher. Every institution of higher education was offered to create their own interinstitutional ways of academic workers' informal education assessment in the system of their professional development.

Key words: academic staff; continuing professional development; higher education institution; models; theoretical approaches and concepts.

https://doi.org/10.28925/1609-8595.2020.4.2

Introduction. Continuing professional development of academic staff is one of the main strategic ways of reforming higher education in Europe, and in Ukraine in particular (Sysoyeva, Protsenko, 2020). Teachers are the agents of changes, who are able to face nowadays challenges and change the system of higher education in Ukraine according to these challenges. The quality of higher education and the perspectives of development of the state in general depend a lot on academic workers. That is why high requirements for professional competencies of academic workers need reformation of the system of continuing development of academic workers in order to make their professional level higher. In Paris Communique (2018) of the ministers of education of the members of the Bologna process it is proclaimed that pedagogical training, continuing professional development of higher education teachers and exploring ways for better recognition of high quality and innovative teaching in their career are one of the ways to promote high quality education (p. 7).

The aim of the article is to substantiate theoretical approaches to continuing development of university academic staff at three methodological levels: philosophical, pedagogical and psychological, and also to define practical models of continuing professional development.

Methods of research. In our research such theoretical methods as analysis, systematization, comparison and 
classification of scientific statements are used in order to define theoretical approaches and practical models of professional development of teachers.

\section{Research results.}

Theoretical approaches to continuing professional development of academic staff. As it is stated by J. Adams et al (2012), though the quality of the educational research is determined by the quality of thinking, which is its basis, and it is often measured by the fact of how well it corresponds to its theoretical bounds, much more researches based on practice and having well-developed methodology are carried out. But the application of the definite theory itself in researches in the area of education gives distinct and reproducible explanations of experiences or social phenomena, and also provides with new understanding of carrying out of the educational practices.

Theoretical basis enriched the research literature for the educational practitioner; sound theoretical underpinnings make it possible to develop and implement effective educational syllabus (Hean et al, 2009, p. 252). So, theoretical substantiation of continuing professional development of teachers of the institutions of higher education is the basis for creation of effective practical models of social pedagogical activities.

Thus, the theoretical foundation of the continuing professional development of teachers of higher education institutions is the basis for establishing effective practical models of continuing professional development.

The scientific literature provides various definitions of continuing professional development. We consider the definition of C. Day (1999) to be the most complete: «Professional development consists of all natural learning experiences and those conscious and planned activities which are intended to be of direct or indirect benefit to the individual, group or school and which contribute, through these, to the quality of education in the classroom. It is the process by which, alone and with others, teachers review, renew and extend their commitment as change agents to the moral purposes of teaching; and by which they acquire and develop critically the knowledge, skills and emotional intelligence essential to good professional thinking, planning and practice with children, young people and colleagues through each phase of their teaching lives» (p. 4).

As noted by M. Karlberg \& Ch. Bezzina (2020), C. Day in his definition emphasizes that it is teachers who play a central and active role in shaping their professional growth (p. 3). Thus, taking into account the self-direction and self-management of their own professional development, we consider the main theoretical approaches that determine the practical models of professional development of teachers of higher education institutions.

To identify the main theoretical approaches to the continuing professional development of academic and teaching staff, we have identified basic theories and concepts at three methodological levels: philosophical, pedagogical and psychological. The leading theories and concepts are identified at each of these levels (Fig. 1).

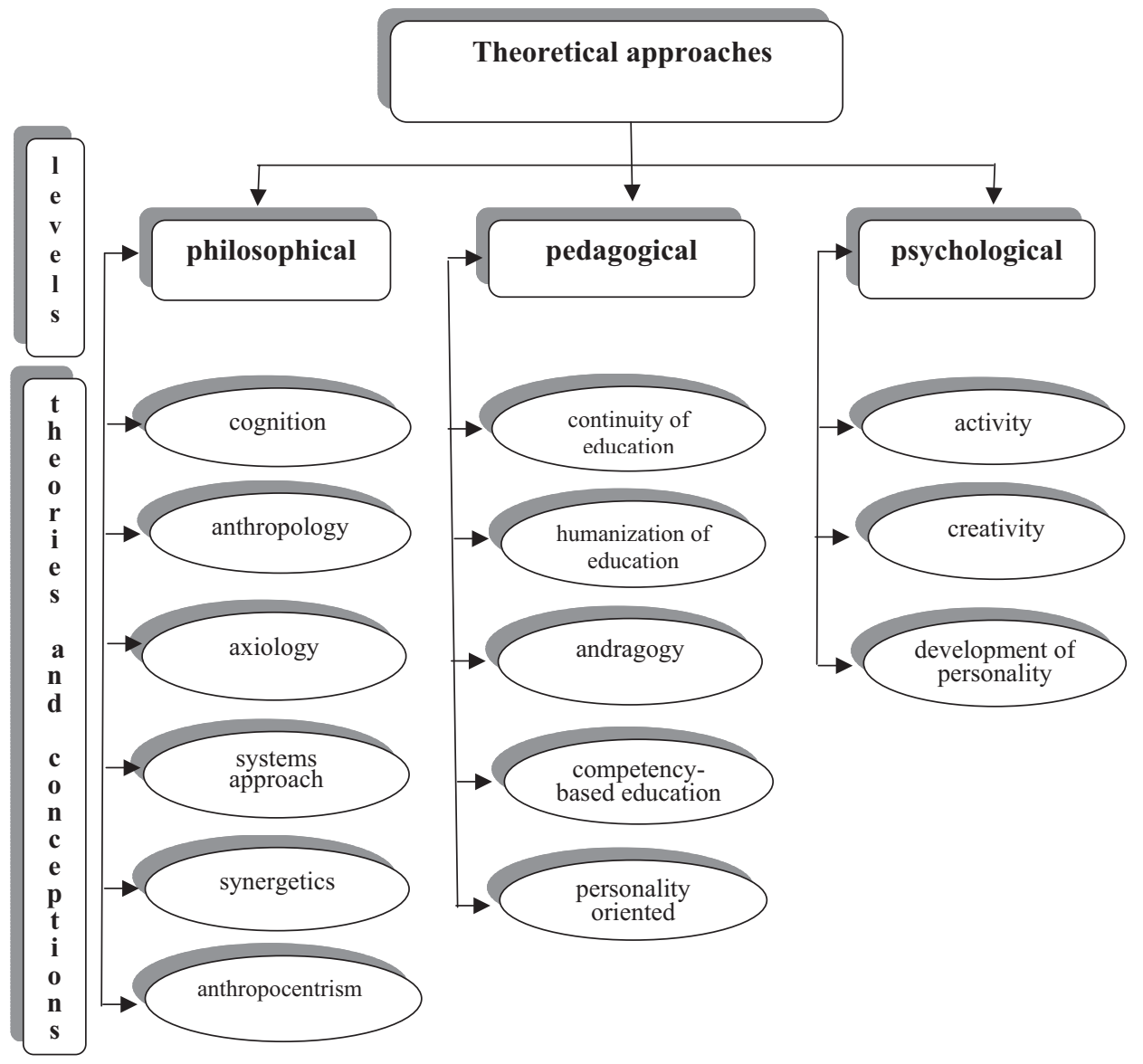

Figure 1. Theoretical approaches to continuing professional development of teachers 
Thus, in our opinion, the methodological principles of continuing professional development of academic and teaching staff are revealed through the relationship and interaction of system-synergetic, anthropological, axiological, acmeological, andragogical, competencybased, personal-activity approaches. The generalization of methodological theories and concepts within these approaches makes it possible to develop practical models for their implementation in the process of continuing professional development of teachers of higher education institutions.

Synergetics reveals the general mechanisms and patterns of self-organization and organization of open systems, which includes the education system. The view of the modern sphere of education as a synergetic system changes our perception of randomness and necessity in educational systems, the irreversibility of educational processes, allows us to understand the nature and essence of entropic processes in educational systems. Thus, fluctuations in social development and social intelligence (innovations, inventions), which affect the education system and are often perceived by educators as «chaos», according to synergetics should be understood as a special kind of regular irregularity, not as the destruction of the education system, and selforganization of open systems are carried out through chaos and continuity (Sysoieva, 2012, p. 25).

Thus, the synergistic coherence of objective and subjective factors makes it possible to predict the purpose, objectives, content, forms and methods of teachers' continuing professional development, coordinate their activities, correct them, build activities on a democratic basis.

A systems approach to the study of the object of pedagogical reality involves its consideration as a system consisting of elements, establishing, classifying and organizing the links between them, identifying system-forming elements that ensure the integrity of functioning. From the standpoint of the systemsynergetic approach, we consider the process of selforganization of continuing professional development of academic staff as a determining trend in the development of abilities for creative search; the process of developing professional competence as an open system with a variety of internal and external links; as an interdisciplinary dialogue of scientific ideas, methods and models of behavior, the disclosure of their potential in the teachers' professional development (Vitvytska, 2015).

Anthropological approach as a methodological basis for the development of the teacher is based on the idea of multidimensionality of human existence and postmodern understanding of the essence of human. Understanding the image of human of the modern cultural epoch forms the idea of his personal existence and coexistence with others, determines the features of human social life, the idea of past and future, which is projected by him in the new socio-cultural conditions.

The anthropological approach is based on knowledge of the features of human life cycles, so it is advisable to pay special attention to the essential characteristics of not only psychophysical but also spiritual and moral development of teachers. Thus, the professional development of academic staff, due to the perception of previously perceived knowledge, interests, habits, the whole content of the mental life of the individual, should be based on the connection with life, reliance on the positive in human, taking into account individual characteristics and his previous professional and personal experience (Kuzmich, 2016).

The axiological approach, closely related to the anthropological one due to the issue of the human image, represents a certain value ideal of human existence.

Values are correlated with all human life, determining the meaningful side of the orientation of the individual and forming the basis of his relations to the world, to other people, himself, the basis of worldview and the core motivation of life activity. The system of values is the link that unites society with the individual and indicates the landmark, perspective, defined by society for each individual, and includes the person in the system of social relations, determines the purpose of any activity and the means by which it is implemented.

The value orientations are the axiological core of the personality, which represents not a system of knowledge, but a system of cognitive formations, which are accepted by the individual as his own internal reference point, motivate and direct his activity. Thus, in the process of professional development objective scientific pedagogical values are subjected in practice, become personal values of the teacher's personality, which is the result of active human activity, an indicator of personal and professional development of the teacher, his pedagogical culture (Slastenin, Podymova, 1997).

Acmeological approach covers the issues of personal and professional development of a person in adulthood. According to N. Kuzmina (2002), acmeology is a branch of scientific knowledge, a set of scientific disciplines. Its object is a person in the self-actualization dynamics of creativity, development, self-improvement, selfdetermination in various areas of life, including education, autonomous professional activity, system of advanced training.

Personality formation and development occur during the process of professional activity and fall under the influence; the characteristics of the working person have a significant impact on the process and results. Thus, acmeological issues of mature people's creative potentials realization are especially relevant for the development and substantiation of professional development methods, clarification of motives in order to gain the excellence in the teacher's professional development.

Andragogical approach, covering the issues of adult learning and education, takes into account the age, psychological, social, professional characteristics of adults, offers to use experience in learning, identifies learning needs, learning goals and ways to achieve it, promotes conditions necessary for human self-realization 
and increasing the efficiency and effectiveness of its activities. Andragogy is based on 6 basic principles developed by M. Knowles, an American researcher of adult education (1970):

- need for knowledge - it is important for a person to know the reason and purpose of learning, how it will take place, what is the benefit for him / her in this learning, what risks he may face;

- autonomy - adult students are self-directed, they take responsibility for their studies;

- the role of experience - the use of students' life experience as a source for learning;

- learning orientation - the use of a flexible course with real-life examples to gain the practical experience needed by students to succeed in their work;

- learning motivation - the development of inner personal motivation, which is driven by ability to get the fastest feedback on the acquired knowledge and skills;

- readiness to learn is determined by specific, practical tasks that meet student's needs and goals.

Personality-activity approach is based on the idea of recognizing the uniqueness and individual value of a person as a subject of activity. Personality is a subject of activity, forming itself in the activity and communication with other people and determining the nature of this activity and communication. The personal component of this approach assumes the unique personality of the student (his motives, goals, psychological composition, identity, self-worth) to be the center of learning, providing an activity component (intensive learning activities of students to achieve a conscious learning goal on an individual development trajectory).

Competency-based approach is a key innovative idea of modern education modernization. This approach focuses on practical achievements in the learning process, so the first priority is not knowledge, but the ability to solve problems in different situations, i.e. to combine the necessary knowledge, skills, moral and social qualities with appropriate action (Sysoieva \& Mospan, 2018). The development and implementation of the methodology of the competency-based approach in higher education is the goal of the European Commission's project Tuning Educational Structures in Europe, which has been implemented in higher education since 2000 to regulate educational structures in Europe. The project defines competencies as a dynamic combination of attributes (with respect to knowledge and its application, skills, responsibilities and attitudes) and they are used to describe the level or extent to which a person is capable of performing them. In the Tuning project competences and skills are understood as including «knowing and understanding» (theoretical knowledge of an academic field, the capacity to know and understand), «knowing how to act» (practical and operational application of knowledge to certain situations), «knowing how to be» (values as an integral element of the way of perceiving and living with others and in a social context) (Tuning, 2000).

It is the competence approach to the professional development of teachers of higher education institutions enshrined in the Law of Ukraine «On Education» (2017), which defines professional development as the acquisition of new and / or improvement of previously acquired competencies within professional activities or knowledge (Article 18).

Thus, the relationship and interaction of theoretical approaches, theories and concepts at the philosophical, pedagogical and psychological levels is the basis for creating practical models of continuing professional development of research and teaching staff of higher education institutions.

Practical models of continuing professional development of academic staff of higher education institutions. Most often, continuing professional development is associated with formal training courses or activities. However, as noted by T. Becher (1996), in practice, teachers use much more models of learning. We consider the classification of A. Kennedy (2005) to be the most complete, who analyzed 9 models of continuing professional development, characterizing them in detail and determining the positive and negative properties of each of them (pp. 219-220):

- The Training model focuses on the competency approach and allows you to improve professional skills. Training is conducted by an expert, an experienced specialist, but, as a rule, it takes place outside the institution where the teacher works, and therefore the negative feature of this model is the lack of connection with the professional context of students;

- The Award-bearing model provides for a university-approved remuneration. On the one hand, it is considered, as a sign of quality assurance and moral encouragement, and on the other - the exercise of control by the bodies that organize and / or finance the professional development of teachers. The disadvantage of this model is the opposition of «academic» and «practical» activities;

- The Deficit model sets a goal in eliminating the professional gaps of an individual teacher. The advantage of this model is the focus on the individual needs of each teacher. However, to put the model to use, as noted by the scientist, there is a need for a basic indicator of competence; in addition, organizational and managerial practices are not taken into account, which can also be the cause of poor work of the teacher;

- The Cascade model demands that trained teachers disseminate information to colleagues. Such a model is cost-effective and can be used in conditions of resource shortage. The disadvantage of this model is its technocracy, because, as a rule, knowledge and skills set priority over attitudes and values;

- The Standards-based model (the author assumes that it can be called competency-based) generates and empirically confirms the relationship between teacher performance and student learning. However, it limits other forms of professional development, does not provide opportunities for the development of critical thinking and reflective analysis of teachers, and does 
not take into account the social, economic, moral goals of education and its future opportunities, i.e. ignores the social context;

- The Coaching / Mentoring model involves the relationship of a more experienced professional who supports a less experienced professional. The advantage of this model is to support the newcomer in obtaining and using relevant knowledge and skills as well as social and moral norms in the educational institution; vocational training takes place in the context of professional activity by exchanging experiences with colleagues, in an atmosphere of more friendly, less hierarchical professional communication. At the same time, participants of this model must have welldeveloped interpersonal skills as well as high motivation for such activities;

- The Community of Practice model is linked to a coaching / mentoring model, but involves more than two people. Joint activities create their own understanding of the joint venture; such a model is a powerful source of modernization of the educational institution, where the total amount of individual knowledge and experience increases significantly due to the collective efforts generated by the richness of connections between individuals. For professional development to take place within this model, it must be neither a form of management nor accountability. However, there is a danger of passivity of some members of the community if other dominant personalities form an understanding of ways of professional development;

- The Action Research model is defined as the study of a social situation, involving the participants themselves as researchers, with a view to improving the quality of professional activity. This model is an alternative to the passive role imposed on teachers in traditional models of professional development: it advocates teachers being encouraged to view research as a process as opposed to merely a product of someone else's activity. The strength of the model is the development of critical thinking and reflective analysis of teachers, as well as the development of communicative competence within professional communities, although collaboration is not mandatory in this model;

- The central characteristic of Transformative model is the combination of practices, processes and conditions that support a transformative agenda. The scientist argues that the transformative model is not a clearly definable model in itself; rather it recognizes the range of different conditions required for transformative practice.

It should be noted that the classification of $\mathrm{A}$. Kennedy (2005) is based on a large number of criteria, but does not take into account informal education individually managed professional development, selforganized development of professional competencies by the teacher, which is not documented.

O. Zhabenko (2019) classified the models of professional development of academic staff of higher education institutions of Ukraine, basing the classification on the criteria associated with professional development in a particular activity (pedagogical, research, methodological, organizational) and form of professional development (institutional, workplace, etc.). According to these criteria, the researcher described the following models (pp. 46-56):

- Scientific and academic model, which gives mainly formal education at the educational and scientific levels of higher education through respectively, postgraduate studies and doctoral training in order to obtain scientific qualifications - doctor of philosophy and doctor of science;

- Practical-science model provides a combination of formal education at the educational scientifical level of high education (through postgraduate study by correspondence course), at the level of adult education, including postgraduate education (training in advanced programs), informal education at the scientific level of high education (by independent preparation of scientific achievements of SPE for defence), non-formal education (participation in workshops, trainings, etc.) in order to obtain scientific qualifications of philosophy doctor (doctor of science) and partial qualifications of the relevant level of the National Qualifications Framework with practical pedagogical activities;

- Practical model provides a combination of practical activities of SPE with formal education at the level of adult education, including postgraduate education (training programs), non-formal education (participation in practical works, trainings, etc.) in order to obtain partial qualifications at the appropriate level of the National Qualifications Framework.

As an advantage of such classification models of professional development of academic staff we note its connection with technologies of career development of teachers.

I. Vorotnikova (2018) proposed a classification of modern models of professional development of teachers, the criteria of which were determined on the basis analysis of qualitative content and organizational indicators of the functioning of modern models of postgraduate pedagogical education. The researcher proposes the following criteria and corresponding models (p. 24):

- training period (short-term, long-term (extended in time) - extended model;

- form of education (full-time, distance, mixed) personality-oriented model;

- forms of support (tutor, trainer, coach, unaccompanied) - a model of mentoring or coaching;

- selection of institutions, experts, trainers, institutes of postgraduate education, Edcamp (informal conferences), mass open online courses (MOOC), internships (including international ones), other organizations (public, commercial) - models based on the use of ICT, diversified, interbranching model;

- the level of professional development of a teacher (professionalization, skill, creativity, innovation) involves participation as a listener, participation as 
a coach, knowledge is transferred in cascade from experts who train new experts, self-education - a socioprofessional model;

- choice the form of education (formal, nonregistered, informal, integration of forms of education) - personality-oriented model;

- place of study (in the workplace (organization, who learn), with separation from production (PIPPE, training centers, internships), dual education (educational institution and enterprise) - «Learning organization», intersectoral model;

- teaching methods (project method, cases, training, exchange of experience, certification programs, webinars, workshops) - models based on the use of ICT, socio-professional model.

It should be noted that the classification proposed by the author applies to the teachers of general secondary education and does not include research as a tool of professional development, so the use of this classification in our study has appropriate limitations. However, its advantage has a fairly wide range of criteria and indicators for classification, which provides opportunities for creative improvement in according to the professional development of workers in the teaching and scientific development of higher education institutions.

Despite the different criteria for the classification of practical models, they cover almost all existing models in Ukraine today, types, forms of professional development of research and teaching staff. However, ignoring informal education remains a big gap. Based on personality, axiological and competence approaches, enshrined in the Law «On Higher Education» (2014), the Law «On Education» (2017), as well as approved by the Cabinet of Ministers of Ukraine «The order of advanced training of teachers and research and teaching staff» (2019), self-education hasn't regulated mechanisms and enrolment criteria, which limits its capabilities and importance for the modernization of the higher education system in Ukraine and for improving the professional activities of each teacher. In accordance with the principles of quality assurance in the European Higher Education Area, universities have the primary responsibility for the quality of their provision and its assurance, and each higher education institution develops its own quality assurance system at institutional level and develops internal standards based on «Standards and Guidelines for Quality Assurance in the European Higher Education Area (ESG)»; so universities should develop internal institutional mechanisms for crediting the results of teachers' self-education.

Conclusions. Taking into account the approaches, theories and concepts at three levels - philosophical, pedagogical and psychological - provide a basis for developing practical models of continuing professional development of research and teaching staff of higher education institutions. We believe that the greatest theoretical and practical potential in this process have the relationship and interaction of systemsynergetic, anthropological, axiological, acmeological, andragogical, competence, personal-activity approaches. Classifications of practical models of professional development of teachers that exist in modern scientific discourse, take into account various criteria - place, forms, methods, terms, forms of learning support and more. However, it remains unaccounted for informal (self-education) of scientific and pedagogical workers, its role and mechanisms of its consideration in improvement of professional activity. Prospects for further research are the development of a practical model of continuing professional development of research and teaching staff in a particular institution of higher education and taking into account the individual educational trajectory of each teacher.

\section{References}

Adams, J., Cochrane, M. \& Dunne, L. (Eds.) (2012). An Introductory Approach with Case Studies. John Wiley \& Sons Ltd.

Becher, T. (1996).The learning professions. Studies in Higher Education, 21 (1), 43-55.

Day, C. (1999). Developing teachers: the challenges of lifelong learning. Falmer.

Hean, S., Craddock, D. and O'Halloran, C. (2009). Learning theories and interprofessional education: a user's guide. Learning in Health and Social Care, 8, 250-262. 10.1111/j.1473-6861.2009.00227.x

Karlberg, M. \& Bezzina, Ch. (2020). The professional development needs of beginning and experienced teachers in four municipalities in Sweden. Professional Development in Education. 10.1080/19415257.2020.1712451

Kennedy, A. (2005). Models of Continuing Professional Development: a framework for analysis. Journal of InService Education, 31 (2), 235-250. 10.1080/13674580500200277

Knowles, M. S. (1970). The Modern Practice of Adult Education: Andragogy versus Pedagogy. Association Press.

Paris Communiqué (2018). https://mon.gov.ua/storage/app/media/news/\%D0\%9D\%D0\%BE\%D0\%B2\%D0\%B8 \%D0\%BD\%D0\%B8/2018/06/06/12/paris-communiqueenua2018.pdf

Sysoieva, S., Mospan, N. (2018). Concept of Competence in the International and National Educational Contexts. Continuing Professional Education: Theory and Practice, 1-2 (54-55), 7-15. https://doi.org/10.28925/16098595.2018(1-2)715

Sysoieva, S., Protsenko, O. (2020). Implementation of the continuing education concept in the European educational area: regulatory provision. Continuing Professional Education: Theory and Practice, 2, 78-84. http://dx.doi. org/10.28925/1609-8595.2020.2.11.

Vitvitska, S. S. (2015). Sistemno-sinergetichnij pidhid do pedagogichnoyi pidgotovki majbutnih magistriv osviti. 
In O. A. Dubasenyuk (Ed.), Profesijna pedagogichna osvita: sistemni doslidzhennya (pp. 92-108). ZhDU im. I. Franka.

Vorotnykova, I. (2018). Modeli profesijnogo rozvitku vchitelya v umovah reformi pislyadiplomnoyi pedagogichnoyi osviti [Models of professional development of teachers in the conditions of the reform of the postal pedagogical education]. Continuing Professional Education: Theory and Practice, 3-4, 21-27. http://dx.doi. org $/ 10.28925 / 1609-8595.2018 .3-4.2127$

Zhabenko, O. V. (2019). Profesijnij rozvitok naukovo-pedagogichnih pracivnikiv universitetiv v umovah integraciyi vishoyi osviti i nauki: modeli i tehnologiya [Professional development of academic staff of universities in the conditions of integration of higher education and science: models and technology]. In O. G. Yaroshenko (Ed.), Teoretichni osnovi i tehnologiya profesijnogo rozvitku naukovo-pedagogichnih pracivnikiv universitetiv v umovah integraciyi vishoyi osviti i nauki : monografiya (pp. 40-83). Institut vishoyi osviti NAPN Ukrayini.

Zakon Ukrainy «Pro vyshchu osvitu» [Law of Ukraine On Higher Education] (2014). https://zakon.rada.gov.ua/ laws/show/1556-18

Zakon Ukrainy «Pro osvitu» [The Law of Ukraine On Education] (2017). https://zakon.rada.gov.ua/laws/show/ 2145-19

Kuzmina, N. V. (2002). Predmet akmeologii [The subject of acmeology]. Politehnika.

Kuzmich, V. K. (2016). Antropologichnij pidhid do vihovannya gumannogo vidnoshennya do lyudini u studentiv pedagogichnih universitetiv [Anthropological approach to the education of humane attitude to man in students of pedagogical universities]. Duhovnist osobistosti: metodologiya, teoriya i praktika, 6 (75), 107-116.

Poryadok pidvishennya kvalifikaciyi pedagogichnih i naukovo-pedagogichnih pracivnikiv. Postanova Kabinetu Ministriv Ukrayini vid 21 serpnya 2019 r. № 800 [The order of advanced training of pedagogical and scientificpedagogical workers. Resolution of the Cabinet of Ministers of Ukraine of August 21, 2019 № 800]. https:// zakon.rada.gov.ua/laws/show/800-2019-\%D0\%BF\#Text

Proekt TYuNING - garmonizaciya osvitnih struktur u Yevropi [Tuning of educational structures in Europe] (2000). http://www.unideusto.org/tuningeu/images/stories/documents/General_Brochure_Ukrainian_version.pdf

Sysoieva, S. (2012). Sfera osviti yak ob’yekt doslidzhennya [The field of education as an object of study]. Osvitologiya, $1,25-29$.

Slastenin, V. A., Podymova, L. S. (1997). Pedagogika: Innovacionnaya deyatelnost [Pedagogy: Innovative activity]. Magistr.

\section{Література}

Adams J., Cochrane M. \& Dunne L. (Eds.). An Introductory Approach with Case Studies. Hoboken: John Wiley \& Sons Ltd, 2012. 225 p.

Becher T. The learning professions. Studies in Higher Education. 1996. № 21 (1). P. 43-55.

Day C. Developing teachers: the challenges of lifelong learning. London: Falmer, 1999. 249 p.

Hean S., Craddock D. \& O'Halloran C. Learning theories and interprofessional education: a user's guide. Learning in Health and Social Care. 2009. № 8. P. 250-262. DOI: 10.1111/j.1473-6861.2009.00227.x

Karlberg M. \& Bezzina Ch. The professional development needs of beginning and experienced teachers in four municipalities in Sweden. Professional Development in Education. 2020. DOI: 10.1080/19415257.2020.1712451

Kennedy A. Models of Continuing Professional Development: a framework for analysis, Journal of In-Service Education. 2005. № 31 (2). P. 235-250. DOI: 10.1080/13674580500200277

Knowles M. S. The Modern Practice of Adult Education: Andragogy versus Pedagogy. New York: Association Press, 1970.384 p.

Paris Communiqué. 2018. URL: https://mon.gov.ua/storage/app/media/news/\%D0\%9D\%D0\%BE\%D0\%B2\%D0 \%B8\%D0\%BD\%D0\%B8/2018/06/06/12/paris-communiqueenua2018.pdf (дата звернення: 27.08.2020).

Sysoieva S., Mospan N. (2018). Concept of Competence in the International and National Educational Contexts. Continuing Professional Education: Theory and Practice. 2018. № 1-2 (54-55). P. 7-15. DOI: https://doi. org/10.28925/1609-8595.2018(1-2)715

Sysoieva S., Protsenko O. Implementation of the continuing education concept in the European educational area: regulatory provision. Continuing Professional Education: Theory and Practice. 2020. № 2. P. 78-84. DOI: http://dx.doi.org/10.28925/1609-8595.2020.2.11

Вітвицька С. С. Системно-синергетичний підхід до педагогічної підготовки майбутніх магістрів освіти. Професійна педагогічна освіта: системні дослідження / за ред. О. А. Дубасенюк. Житомир : ЖДУ ім. I. Франка, 2015. С. 92-108.

Воротникова I. Моделі професійного розвитку вчителя в умовах реформи післядипломної педагогічної освіти. Неперервна професійна освіта: теорія і практика. 2018. № 3-4. C. 21-27. DOI: 10.28925/16098595.2018.3-4.2127.

Жабенко О. В. Професійний розвиток науково-педагогічних працівників університетів в умовах інтеграції вищої освіти і науки: моделі і технологія. Теоретичні основи і технологія професійного 
розвитку науково-педагогічних працівників університетів в умовах інтеграції вищої освіти і науки: монографія / Авторський колектив: О. Г. Ярошенко, О. В. Жабенко, Ю. А. Скиба, Н. О. Дівінська, I. Ю. Регейло, Г. П. Чорнойван; за ред. О. Г. Ярошенко. Київ: Інститут вищої освіти НАПН України, 2019. C. 40-83.

Закон України «Про вищу освіту». 2014. URL: https://zakon.rada.gov.ua/laws/show/1556-18 (дата звернення: 25.08.2020).

Закон України «Про освіту». 2017. URL: https://zakon.rada.gov.ua/laws/show/2145-19 (дата звернення: 25.08.2020).

Кузьмина Н. В. Предмет акмеологии. Санкт-Петербург: Политехника, 2002. 189 с.

Кузьмич В. К. Антропологічний підхід до виховання гуманного відношення до людини у студентів педагогічних університетів. Духовність особистості: методологія, теорія і практика. 2016. № 6 (75). С. 107-116.

Порядок підвищення кваліфікації педагогічних і науково-педагогічних працівників. Постанова Кабінету Міністрів України від 21 серпня 2019 р. № 800. URL: https://zakon.rada.gov.ua/laws/show/8002019-\%D0\%BF\#Text (дата звернення: 25.08.2020).

Проект ТЬЮНІНГ - гармонізація освітніх структур у Європі. URL: http://www.unideusto.org/tuningeu/ images/stories/documents/General_Brochure_Ukrainian_version.pdf (дата звернення: 28.08.2020).

Сисоєва С. О. Сфера освіти як об’єкт дослідження. Освітологія. 2012. № 1. С. $25-29$.

Сластенин В. А., Подымова Л. С. Педагогика: Инновационная деятельность. Москва: Магистр, 1997. $224 \mathrm{c}$.

\title{
БЕЗПЕРЕРВНИЙ ПРОФЕСІЙНИЙ РОЗВИТОК НАУКОВО-ПЕДАГОГІЧНИХ ПРАЦІВНИКІВ УНІВЕРСИТЕТУ: ТЕОРЕТИЧНІ ПІДХОДИ І МОДЕЛІ
}

\author{
Линьова Ірина, кандидат педагогічних наук, доцент, \\ старший науковий співробітник відділу інтеграції вищої освіти і науки, \\ Інститут вищої освіти НАПН України, \\ вул. Бастіонна, 9, 01014 Київ, Україна, \\ i.lynova1704@gmail.com
}

Бульвінська Оксана, кандидат педагогічних наук, старший науковий співробітник, старший науковий співробітник НДЛ освітології,

Київський університет імені Бориса Грінченка, вул. Тимошенка, 13-б, 04212 Київ, Україна, o.bulvinska@kubg.edu.ua

У статті акцентовано, що саме застосування певної теорії в освітніх дослідженнях дає чітке $i$ відтворюване пояснення професійного досвіду, стає основою розроблення практичних моделей освітньої діяльності. Запропоновано класифікувати теоретичні підходи і концепиї до безперервного професійного розвитку на філософському, педагогічному та психологічному рівнях. Доведено, що узагальнення взаємопов'язаних $i$ взаємодіючих системно-синергетичного, антропологічного, аксіологічного, акмеологічного, андрагогічного, компетентнісного, особистісно-діяльнісного підходів обгрунтовують мету, завдання, зміст, форми і методи безперервного професійного розвитку науково-педагогічних працівників університету, враховують самоспрямованість і самокерованість власного професійного розвитку і в той же час дають змогу координувати діяльність викладачів, своєчасно вносити корективи, вибудовувати діяльність на демократичних засадах. Визначено, що розроблені з урахуванням цих підходів практичні моделі професійного розвитку дають можливість викладачам розробляти власну освітню траєкторію, самостійно обирати конкретні форми, види, напрями та суб'єктів надання освітніх послуг. Проте нерозв'язаною проблемою залишається відсутність врегульованих механізмів $i$ критеріїв зарахування інформальної освіти, що визначається як індивідуально керований професійний розвиток, самоорганізоване здобуття викладачем професійних компетентностей, яке не фіксується документально. Це обмежує можливості самоосвіти і ї̈ значення для модернізацї системи вищої освіти в Україні $i$ для удосконалення професійної діяльності кожного викладача. Запропоновано кожному закладу вищої освіти розробити власні внутрішньоінституційні механізми зарахування результатів інформальної освіти науково-педагогічних працівників у системі професійного розвитку.

Ключові слова:безперервний професійний розвиток; заклад вищоїосвіти; моделі; науково-педагогічні працівники; теоретичні підходи і концепцї. 


\section{НЕПРЕРЫВНОЕ ПРОФЕССИОНАЛЬНОЕ РАЗВИТИЕ НАУЧНО-ПЕДАГОГИЧЕСКИХ РАБОТНИКОВ УНИВЕРСИТЕТА: ТЕОРЕТИЧЕСКИЕ ПОДХОДЫ И МОДЕЛИ}

Линева Ирина, кандидат педагогических наук, доцент, старший научный сотрудник отдела интеграции высшего образования и науки, Институт высшего образования НАПН Украины, ул. Бастионная, 9, 01014 Киев, Украина, i.lynova1704@gmail.com

Бульвинская Оксана, кандидат педагогических наук, старший научный сотрудник, старший научный сотрудник научно-исследовательской лаборатории освитологии, Киевский университет имени Бориса Гринченко, ул. Тимошенко, 13-б, 04212 Киев, Украина, o.bulvinska@kubg.edu.ua

В статье классифицированы теоретические подходы иконщепщиикнепрерывному профессиональному развитию на философском, педагогическом и психологическом уровнях. Доказано, что обобщение взаимосвязанных и взаимодействующих системно-синергетического, антропологического, аксиологического, акмеологического, андрагогического, компетентностного, личностно-деятельностного подходов обосновывают цели, задачи, содержание, формы и методы непрерывного профессионального развития научно-педагогических работников университета, учитывают самонаправленность и самоуправляемость собственного профессионального развития и в то же время позволяют координировать деятельность преподавателей, своевременно вносить коррективы, выстраивать деятельность на демократических началах. Определено, что разработанные с учетом этих подходов модели профессионального развития дают возможность преподавателям разрабатывать собственную образовательную траекторию, самостоятельно выбирать конкретные формы, виды, направления и субъектов предоставления образовательных услуг. Однако нерешенной проблемой остается отсутствие урегулированных механизмов и критериев зачисления информального образования, которое определяется как индивидуально управляемое развитие, самоорганизующееся получение преподавателем профессиональных компетениий, не фиксируемое документально. Это ограничивает возможности самообразования и ее значение для модернизащии системы высшего образования в Украине и для совершенствования профессиональной деятельности каждого преподавателя.

Ключевые слова: высшие учебные заведения; модели; научно-педагогические работники; теоретические подходы и кониепции; непрерывное профессиональное развитие.

Article was: Received 01.09.2020 Accepted 26.11.2020 